\title{
UPAYA PENINGKATAN DAYA SAING PRODUK OLAHAN PUCUK DAUN TEH RAKYAT DI KECAMATAN BOJONG KABUPATEN PURWAKARTA
}

\author{
Effort For Improving Competitive Power Products Powder Top Of Tea Leaves In Bojong District \\ Purwakarta Regency
}

\author{
Rani Andriani Budi Kusumo, Anne Charin, Gema Wibawa Mukti \\ Program Studi Agribisnis, Fakultas Pertanian, Universitas Padjadjaran \\ raniandriani081@gmail.com
}

\begin{abstract}
Acreage and production of tea plant in Purwakarta decreased compared to previous years. Price of tea leaf is less favorable making farmers less eager to continue to pursue this commodity. Sindangpanon farmer group seeks to increase the value added tea leaf to process into dry tea, but various obstacles make this business has not developed. The purpose of this study was to: 1) analyze the problems faced by farmers' groups in running the business processing tea leaf; 2) analyze the impact of efforts to increase the capacity of farmer groups to produce competitive products. This study is an action research and designed with a qualitative design. Informants in this study is the management and members of farmer groups Sindangpanon well as the staff of the Department of Agriculture, Plantation and forestry, PurwakartaDistrict. Data were analyzed with descriptive analysis. The results showed the tea leaf processing enterprises difficult to develop due to lack of competitive products, the market is still limited and the managerial ability needs to be improved. Event strengthening the capacity of farmer groups that do have an impact on increasing the knowledge and skills of the group members in running the business and increased sales volume.
\end{abstract}

Key words : competitiveness, product, tea, farmers group.

\begin{abstract}
ABSTRAK
Di Kabupaten Purwakarta, luas areal dan produksi teh rakyat mengalami penurunan dibandingkan tahun-tahun sebelumnya. Harga pucuk daun teh yang rendah membuat petani kurang bersemangat untuk terus mengusahakan komoditas ini. Kelompok tani Sindangpanon berupaya untuk meningkatkan nilai tambah pucuk daun teh dengan mengolahnya menjadi teh kering, namun berbagai kendala membuat usaha ini belum berkembang. Tujuan dari penelitian ini adalah untuk : 1) menganalisis masalah yang dihadapai oleh kelompok tani dalam menjalankan usaha pengolahan pucuk daun teh; 2) menganalisis dampak dari upaya peningkatan kapasitas kelompok tani agar menghasilkan produk yang berdaya saing. Penelitian ini merupakan action research dan didesain dengan desain kualitatif. Informan dalam penelitian ini adalah pengurus dan anggota kelompok tani Sindangpanon serta staf Dinas Pertanian, Perkebunan dan Kehutanan Kabupaten Purwakarta. Data dianalisis dengan analisis deskriptif. Hasil penelitian menunjukkan usaha pengolahan pucuk daun teh sulit berkembang disebabkan karena produk kurang memiliki daya saing, pasar yang masih terbatas dan kemampuan manajerial yang perlu ditingkatkan. Kegiatan penguatan kapasitas kelompok tani yang dilakukan memberikan dampak pada meningkatnya pengetahuan dan keterampilan anggota kelompok dalam menjalankan usaha serta meningkatnya volume penjualan.
\end{abstract}

Kata kunci : daya saing, produk, teh, kelompok tani 


\section{PENDAHULUAN}

Indonesia merupakan salah satu dari sepuluh negara produsen sekaligus eksportir utama teh dunia. Sepuluh negara pengimpor teh Indonesia yaitu : Inggris, Rusia, Malaysia, Pakistan, AS, Jerman, Polandia, Belanda, Australia dan Arab Saudi. Produksi teh Indonesia saat ini dihasilkan dari 13 provinsi, yaitu dari seluruh provinsi di Sumatera, seluruh provinsi di Jawa kecuali DKI Jakarta dan dua provinsi di Sulawesi yaitu Sulawesi Tengah dan Sulawesi Selatan. Diantara ketigabelas provinsi tersebut hanya tiga propinsi yang menguasai produksi teh dalam negeri yaitu provinsi Jawa Barat, Sumatera Utara dan Jawa Tengah. Provinsi Jawa Barat menempati urutan pertama dalam produksi teh, dengan luas areal tanam berkisar 107.040 hektar (Disbun Jabar, 2013), hal ini disebabkan karena kondisi lahan dan iklimnya yang cocok untuk budidaya tanaman teh. Produksi teh yang dihasilkan oleh provinsi Jawa Barat berasal dari Perkebunan Rakyat (PR), Perkebunan Besar Negara (PBN) dan Perkebunan Besar Swasta (PBS).

Kabupaten Purwakarta merupakan salah satu daerah penghasil teh di Provinsi Jawa Barat, dimana perkebunan teh di Kabupaten Purwakarta sebagian besar merupakan perkebunan teh rakyat yang tersebar di lima kecamatan, yaitu Kecamatan Darangdan, Bojong, Wanayasa, Kiarapedes dan Kecamatan Pondoksalam

Kondisi perkebunan teh rakyat, khususnya di Kabupaten Purwakarta, selama satu dekade terakhir dapat dikatakan kurang menggembirakan, indikasi yang paling terlihat adalah maraknya alih fungsi lahan perkebunan teh rakyat. Pada Tabel 1 di bawah ini dapat dilihat penurunan luas areal dan produksi teh rakyat selama beberapa tahun terakhir. Berdasarkan hasil wawancara dengan beberapa orang petani, faktor yang menjadi pemicu alih fungsi lahan perkebunan teh rakyat adalah harga komoditas teh yang kurang menguntungkan. Hal tersebut membuat petani tidak termotivasi untung mengembangkan usahanya.

Sebagian petani yang tergabung dalam Kelompok Tani Teh Sindangpanon Kecamatan Bojong Kabupaten purwakarta, sejak kurang lebih lima tahun belakangan ini telah berupaya meningkatkan nilai tambah pucuk teh yang mereka hasilkan menjadi teh kering dalam bentuk 'Teh Gelang' yang dijual dengan harga Rp. 100.000/Kg, dan juga menjadi "White Tea", yang dijual dengan harga Rp. 1.200.000,00/Kg. Namun usaha tersebut masih berskala kecil, dan lingkup pemasaran nya pun masih bersifat lokal di seputar Kabupaten Purwakarta saja. Dalam perjalanan nya, skala usaha olahan pucuk daun teh dapat dikatakan belum ada perkembangan yang berarti. Menurut informan dari Dinas Pertanian, Perkebunan dan Kehutanan Kabupaten Purwakarta, sebagian besar petani di Kabupaten Purwakarta diniai belum siap bersaing untuk terhadap usaha ini yang masih tradisional. Kurangnya motivasi petani untuk memperbaiki sistem usaha nya juga merupakan penghambat dalam menghadapi pasar bebas.

Untuk itu diperlukan penguatan kelompok tani sebagai kelompok usaha pengolahan teh rakyat agar lebih memiliki daya saing. Penelitian ini merupakan action research yang bertujuan untuk : 1) memetakan permasalahan yang dihadapi kelompok tani dalam mengembangkan usaha pengolahan pucuk daun teh rakyat; 2) Menganalisis dampak dari kegiatan penguatan kapasitas kelompok tani terhadap daya saing produk olahan pucuk daun teh rakyat. 
Tabel 1. Luas Areal dan Produksi Tanaman Teh Rakyat di Kabupaten Puwakarta

\begin{tabular}{crrrrr}
\hline Tahun & TBM (Ha) & TM (Ha) & TR (Ha) & Jumlah (Ha) & $\begin{array}{c}\text { Produksi } \\
\text { (Ton) }\end{array}$ \\
\hline 2014 & 391,83 & 3953,40 & 169,78 & 4515,01 & 5598,64 \\
2013 & 430,49 & 3944,64 & 149,38 & 4524,51 & 5584,73 \\
2012 & 454,49 & 3914,64 & 146,38 & 4515,51 & 5397,59 \\
2011 & 1663,50 & 7364,86 & 431,68 & 9460,04 & 8298,21 \\
2010 & 1571,01 & 7144,53 & 447,79 & 9163,33 & 9606,52 \\
\hline
\end{tabular}

Ket : TBM : Tanaman Belum Menghasilkan. TM : Tanaman Menghasilkan. TR : Tanaman Rusak Sumber : Badan Pusat Statistik, 2015

\section{METODE PENELITIAN}

Penelitian ini merupakan action research untuk mengevaluasi dampak kegiatan penguatan kapasitas kelompok tani terhadap saya saing produk olahan teh rakyat. Penelitian dilakukan di Kelompok tani Sindangpanon Kecamatan Bojong Kabupaten Purwakarta. Penelitian ini merupakan penelitian kualitatif yang dilakukan dengan teknik studi kasus. Penelitian kualitatif merupakan penelitian yang digunakan untuk menyelidiki, menemukan, menggambarkan, dan menjelaskan kualitas atau keistimewaan dari pengaruh sosial yang tidak dapat dijelaskan, diukur atau digambarkan melalui pendekatan kuantitatif. Teknik penelitian yang digunakan dalam penelitian ini adalah studi kasus. Studi kasus adalah suatu bentuk penelitian yang mendalam tentang suatu aspek lingkungan sosial termasuk manusia di dalamnya. Studi kasus yang baik harus dilakukan secara langsung dalam kehidupan sebenarnya dari kasus yang diselidiki. Untuk itu data studi kasus dapat diperoleh dari semua pihak yang mengetahui dan mengenalnya secara baik (Nawawi, 2001).

Jenis data yang dikumpulkan terdiri dari data primer dan data sekunder. Data primer diperoleh dari hasil pengamatan dan wawancara mendalam kepada informan yaitu Kepala Seksi Perkebunan Dinas Pertanian, Perkebunan dan Kehutanan Kabupaten Purwakarta serta beberapa orang petani yang merupakan ketua serta anggota kelompok tani Sindangpanon.

Untuk menganalisis permasalahan yang dihadapi kelompok tani dalam menjalankan usaha olahan pucuk daun tehrakyat, dilakukan dengan menyusun pohon masalah. Analisis deskriptif digunakan untuk menganalisis dampak kegiatan penguatan kapasitas kelompok tani. Analisis deskriptif merupakan suatu metode dalam meneliti suatu kelompok manusia, suatu objek, kondisi, sistem pemikiran, ataupun suatu kelas peristiwa pada masa sekarang. Adapun tujuan dari analisis deskriptif ini adalah untuk membuat deskripsi secara sistematis, dan faktual mengenai fakta-fakta, sifat-sifat, serta hubungan antara fenomena yang diselidiki Nazir (2005).

\section{HASIL DAN PEMBAHASAN}

\section{Permasalahan yang Dihadapi Kelompok Tani dalam Menjalankan Usaha Produk Olahan Pucuk Daun Teh}

Kelompok tani Sindangpanon selama kurang lebih lima tahun terakhir telah menjalankan usaha pengolahan pucuk daun teh. Pucuk daun teh yang dihasilkan oleh petani anggota diolah menjadi teh 'gelang' dan juga white tea yang bernilai ekonomis tinggi. Namun berdasarkan hasil wawancara dengan informan, diketahui permasalahan yang dihadapi kelompok tani yaitu usaha yang tidak berkembang jika dilihatdari volume penjualan produk yang stagnan bahkan cenderung menurun. 
Pada Gambar 1 dapat dijelaskan bahwa permasalahan kurang berkembangnya usaha pengolahan pucuk daun teh yang dilakukan oleh kelompok tani Sindangpanon. Dari segi produk, masalah yang dihadapi adalah produk yang dihasilkan kurang memiliki daya saing di pasar, dikarenakan mereka belum sepenuhnya menerapkan strategi pemasaran yang tepat. Salah satu contoh kurangnya daya saing produk adalah kemasan yang masih sehingga kurang menarik minat pembeli untuk membeli produk. Padahal untuk menghadapi pasar, termasuk pasar bebas ASEAN diperlukan peningkatan daya saing komoditas pertanian yang tidak saja ditentukan oleh mutu produk yang baik, tetapi juga dituntut harga produk yang kompetitif serta ramah lingkungan dalam proses produksinya.
Dalam hal pemasaran produk, permasalahan yang dihadapi terkait pemasaran produk yang masih terbatas. Produk teh gelang yang dihasilkan sebagian besar dipasarkan di pasar tradisional lokal dan juga warung-warung di sekitar Desa Sindangpanon. Untuk produk white tea sebagian besar dipasarkan berdasarkan permintaan pembeli di Jakarta dan dijual dalam bentuk yang belum dikemas. Kelompok tani memiliki keinginan untuk dapat mengemas produk mereka sendiri dan memiliki merk sendiri agar pemasaran produk lebih berkembang. Keterbatasan pasar juga disebabkan karena selama ini kelompok tani belum melakukan strategi promosi bagi produk yang dihasilkan.

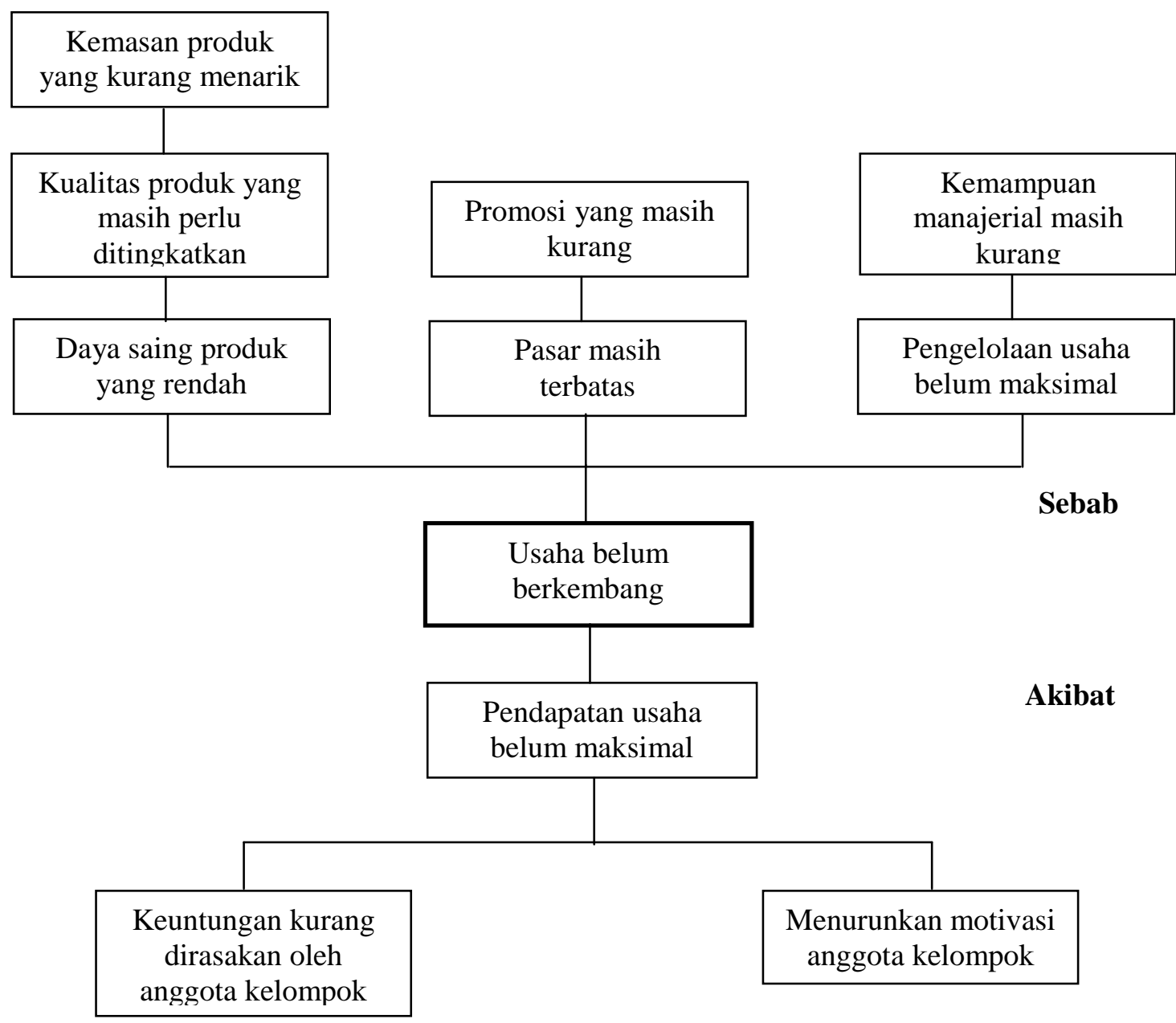

Gambar 1. Pohon Masalah yang Dialami Kelompok Tani Sindangpanon dalam Pengelolaan Usaha Pengolahan Pucuk Daun Teh Rakyat 
Dari segi manajerial, kemampuan mengelola usaha secara professional juga menjadi faktor penghambat berkembangnya usaha. Meskipun usaha pengolahan pucuk daun teh bukan merupakan usaha utama bagi kelompok tani, namun apabila dikelola secara professional, usaha tersebut dinilai akan mampu menghasilkan keuntungan yang lebih optimal. Belum berkembangnya usaha yang dijalankan oleh kelompok tani mengakibatkan keuntungan dari usaha ini juga belum maksimal, sehingga anggota belum merasakan nilai tambah dari usaha ini.

Berdasarkan pemetaan masalah yang dihadapi oleh kelompok tani, maka diperlukan kegiatan yang bertujuan untuk meningkatkan daya saing produk olahan pucuk daun teh yang dihasilkan. Untuk itu, peningkatan daya saing, dalam rangka ekspansi pasar, produk harus memenuhi standar kualitas dan persyaratan pasar regional maupun internasional. Produk yang dihasilkan mitra setidaknya harus memiliki sertifikat PIRT dan juga label halal. Selain itu, tampilan produk juga harus menarik agar meningkatkan nilai jual produk. Dari segi harga, produk yang dihasilkan mitra juga harus bisa bersaing di pasar. Dari segi distribusi, perluasan pasar dapat dilakulan melalui bantuan teknologi internet, pembuatan website dapat membantu perluasan wilayah pemasaran, dan sekaligus sebagai media promosi. Selain itu, penguatan kelompok usaha juga dilakukan melalui kegiatan pelatihan dan pendampingan.

\section{Upaya Peningkatan Daya Saing Produk Olahan Pucuk Daun Teh Rakyat}

Untuk membantu kelompok tani dalam hal pengelolaan usaha dan peningkatan daya saing produk olahan pucuk daun teh rakyat, Tim PKM Fakultas Pertanian Unpad melaksanakan serangkaian kegiatan untuk membantu kelompok tani Sindangpanon agar mampu menghasilkan produk yang lebih berdaya saing. Kegiatan yang dilakukan lebih menekankan pada penguatan atribut produk olahan pucuk daun teh. Tjiptono (2007) menjelaskan bahwa atribut produk merupakan unsur produk yang dipandang penting oleh konsumen dan merupakan dasar pengambilan keputusan pembelian.

Kualitas merupakan atribut utama yang mendorong konsumen untuk membeli sebuah produk. Dari segi kualitas, produk teh gelang dan white tea yang dihasilkan kelompok tani sudah tergolong baik. Produk yang dihasilkan telah memiliki sertifikat PIRT dari Dinas Kesehatan Kabupaten Purwakarta dan juga sertifikat halal dari MUI. Pelatihan yang diberikan semata mata bertujuan untuk mengajak anggota kelompok untuk bersama-sama menjaga kualitas produk yang dihasilkan, dimulai dari menjaga kualitas bahan baku dan, mengolah pucuk daun teh dengan memperhatikan standar keamanan produk.

Selain kualitas produk, kemasan merupakan salah satu atribut produk yang menggambarkan karakteristik produk yang melengkapi fungsi dasar produk. Kemasan bukan hanya berfungsi sebagai wadah bagi produk, namun juga harus dapat melindungi produk dan memberikan identitas bagi produk itu sendiri. Oleh karena itu, bagi produk pangan selain harus memiliki standar food grade, kemasan juga harus didesain secara menarik dan fungsional agar mampu menarik minat konsumen untuk membeli produk. Produk teh gelang yang dihasilkan kelompok tani pada awalnya hanya dikemas dalam kemasan plastic tipis dengan label yang sederhana, sedangkan produk white tea dikemas dalam plastik dan kertas, juga dengan label yang sederhana. 

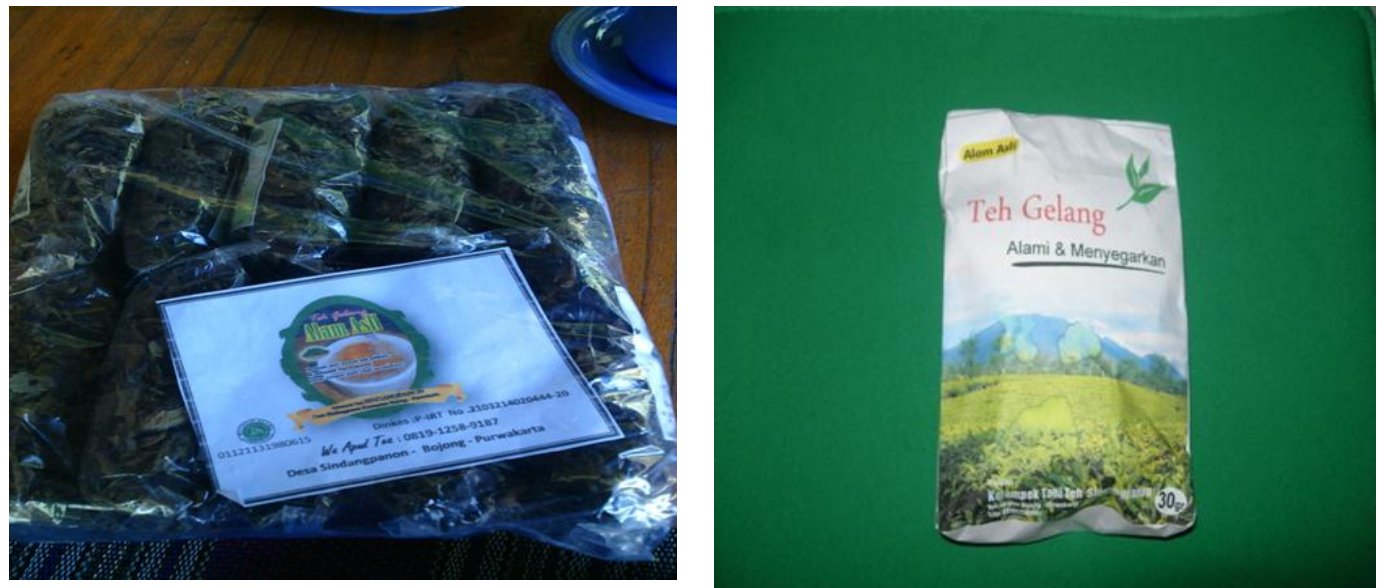

Gambar 2. Kemasan Awal Produk Teh Gelang dan White Tea
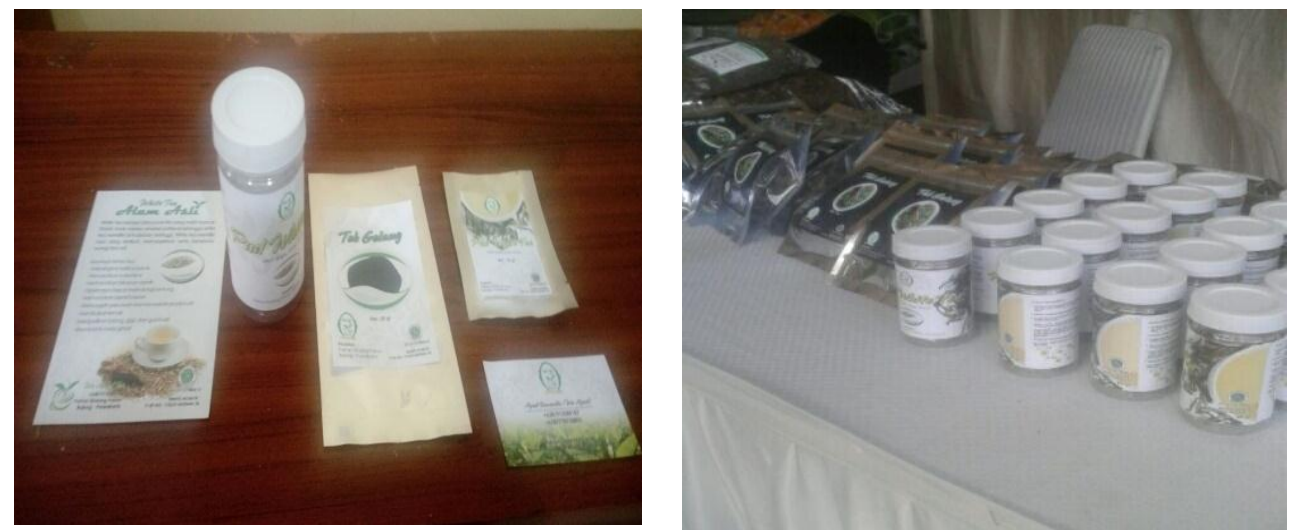

Gambar 3. Kemasan Baru Produk Teh Gelang dan White Tea

Kelompok tani Sindangpanon mendapatkan pelatihan teknis mengenai cara membuat kemasan yang baik dan juga diberikan bantuan untuk membuat kemasan yang baik dan menarik agar meningkatkan nilai tambah produk dan mendorong konsumen untuk melakukan pembelian. Kemasan teh gelang yang baru terbuat dari kertas alumunium yang memenuhi standar kemasan produk pangan, sedangkan kemasan white tea terbuat dari botol plastic tebal dan diberi tutup lapisan alumunium untuk menjaga kualitas produk. Label pada kemasan juga dirancang untuk memberikan informasi kepada konsumen mengenai identitas produk dan juga produsen, serta mencantumkan kandungan serta khasiat produk juga cara penyajian produk.

Untuk memperluas pasar, pengurus dan anggota kelompok tani Sindangpanon diperkenalkan untuk mencoba pemasaran produk secara online, dengan diberikan pelatihan pemasaran online secara sederhana dengan membuka akun di beberapa situs pemasaran online. Diharapkan dengan kegiatan ini akan membuka alternatif dan juga peluang pasar baru bagi produk teh gelang dan white tea yang dihasilkan oleh kelompok tani Sindangpanon.

Kegiatan promosi untuk memperluas akses pasar juga dilakukan oleh kelompok tani Sindangpanon dengan didukung oleh Dinas Pertanian, Perkebunan dan Kehutanan Kabupaten Purwakarta berupa keikutsertaan kelompok tani Sindangpanon dalam berbagai kegiatan pameran, seperti Bandung Tea Festival 2016 dan juga pameran di Kabupaten Subang. 


\section{Dampak Kegiatan Penguatan Kapasitas Kelompok Tani dalam Meningkatkan Daya Saing Produk Olahan Pucuk Daun Teh Rakyat}

Dampak dari kegiatan ini yang dapat terukur diantaranya adalah meningkatnya pengetahuan dan keterampilan peserta mengenai pengelolaan usaha, pentingnya kemasan dan juga cara memasarkan produk secara online. Selain itu perubahan juga diamati dari meningkatnya volume penjualan produk olahan pucuk daun teh.

Kesiapan kelompok tani dalam mengelola usaha terlihat dari komitmen anggota kelompok untuk bersama-sama mendukung usaha ini. Sebagian anggota kelompok terlibat langsung dalam mengelola usaha. Meskipun usaha ini masih berskala kecil, namun kelompok tani Sindangpanon telah mencoba menerapkan aspek manajemen dengan baik.

Dari aspek keuangan, kelompok tani Sindangpanon telah melakukan pencatatan keuangan. Dengan melakukan pencatatan keuangan, setiap aktivitas transaksi dapat dilaporkan dan menjadi bahan informasi mengenai sumber-sumber ekonomi, kewajiban serta modal kelompok. Dari aspek produksi, kelompok lebih memperhatikan cara pengolahan produk agar sesuai dengan standar keamanan pangan, selain itu perencanaan produksi juga mulai dilakukan untuk memenuhi permintaan pasar. Tampilan produk juga lebih menarik sehingga dapat menjangkau pasar di luar pasar tradisional yang selama ini menjadi tujuan utama bagi produk the gelang (Gambar 3). Dalam aspek pemasaran, kegiatan promosi dan penjualan mulai dilakukan secara terencana, agar kelompok dapat menyesuaikan permintaan dan ketersediaan produk.

Perbaikan berbagai aspek tersebut juga berdampak pada volume penjualan produk teh gelang selama beberapa bulan terakhir. Sebelum adanya kegiatan penguatan kapasitas kelompok dalam menjalankan usaha, penjualan produk teh gelang ke pasar tradisional yaitu pasar di sekitar Kabupaten Purwakarta rata-rata $50 \mathrm{Kg}$ per bulan. Produk teh gelang dijual dalam kemasan plastic kecil berisi 20 gr dengan harga Rp. 1000/kemasan. Setelah adanya perbaikan kemasan, produk teh gelang dapat memasuki pasar lain, seperti toko oleh-oleh, stand pameran serta penjualan perorangan. Dengan bobot per kemasan yang sama (20 gr), produk teh gelang dijual dengan harga Rp. 5000/kemasan. Berbagai penelitian menunjukkan bahwa kemasan dapat meningkatkan nilai jual suatu produk, karena dengan kemasan yang baik konsumen akan bersedia membayar lebih. Di pasar yang baru, penjualan teh gelang dalam satu bulan rata-rata berkisar $30 \mathrm{Kg}$ (Tabel 2).

Sementara untuk produk white tea, permintaan selain datang dari perorangan dalam bentuk yang belum dikemas, permintaan produk white tea yang dikemas dalam kemasan 20 gr dan 50 gr (Gambar 3) juga mulai datang dari beberapa toko oleh-oleh di seputar Kota Purwakarta. Meningkatnya permintaan produk teh gelang dan white tea tentunya akan berdampak pada peningkatan pendapatan kelompok tani Sindangpanon.

Tabel 2. Volume Penjualan Teh Gelang Produksi oleh Poktan Sindangpanon

\begin{tabular}{lcc}
\hline \multicolumn{1}{c}{ Pasar } & Sebelum & Sesudah \\
\hline Tradisional (pasar tradisional, warung) & $50 \mathrm{Kg} / \mathrm{bulan}$ & $50 \mathrm{Kg} / \mathrm{bulan}$ \\
Perluasan pasar (pameran, toko oleh-oleh, café) & - & $30 \mathrm{Kg} / \mathrm{bulan}$ \\
\hline
\end{tabular}




\section{KESIMPULAN}

Kendala yang dihadapi kelompok tani Sindangpanon dalam pengelolaan usaha pengolahan pucuk daun teh disebabkan karena produk yang dihasilkan kurang memiliki daya saing dan pasar yang masih terbatas. Pendampingan pada kelompok tani dilakukan melalui kegiatan pelatihan dan perbaikan desain kemasan serta pengenalan pasar melalui media online. Kegiatan tersebut memberikan dampak pada perluasan akses pasar dan juga peningkatan volume penjualan produk teh gelang dan white tea. Komitmen serta motivasi yang kuat dari anggota kelompok sangat diperlukan untuk menjaga keberlangsungan usaha yang dijalankan oleh kelompok tani. Dukungan dari berbagai pihak juga sangat diperlukan agar kelompok tani menjadi lebih berdaya dalam usaha peningkatan nilai tambah pucuk daun teh rakyat.

\section{Ucapan Terima Kasih}

Kami mengucapkan terima kasih kepada Kementrian Riset, Teknologi dan Pendidikan Tinggi yang telah memberikan dukungan dana bagi kegiatan ini dalam skema Iptek bagi Masyarakat Tahun Anggaran 2016.

\section{DAFTAR PUSTAKA}

Badan Pusat Statistik. 2015. Kabupaten Purwakarta dalam Angka. BPS Kabupaten Purwakarta.

Hikmat, Harry. 2001. Strategi Pemberdayaan Masyarakat. Bandung : Humaniora Utama

Nawawi, Hadari. 2001. Metode Penelitian Sosial. Yogyakarta : Gajah Mada Offset.

Nazir, Moh. 2005. Metode Penelitian. Jakarta : Ghalia Indonesia

Statistik Perdagangan Luar Negeri Indonesia, 2012

Statistik Sebaran Tanaman Perkebunan Prov Jabar, 2013. Diakses melalui http://disbun.jabarprov.go.id, tanggal 11 Februari 2016

Tjiptono, Fandy. 2007. Strategi Pemasaran Edisi Ke 2. Yogyakarta : Penerbit Andi. 